\title{
SOCIAL COMMUNICATION IN THE FIQH TAFSÎR: A Study of Muslims and Non-Muslims in the Qur'anic Interpretation
}

\author{
Ali Hamdan \\ Universitas Islam Negeri Maulana Malik Ibrahim \\ Jl. Gajayana No. 50 Malang 65144 \\ e-mail: hamdan@syariah.uin-malang.ac.id
}

\begin{abstract}
This study is driven by a reality showing a social communication in a factual Fiqh interpretation between Muslim and non-Muslim in the Qur'an. Therefore, the question that needs to be answered is "how the fiqh interpretation can depict the social communication between Muslims and non-Muslims in the Qur'an?" This is a qualitative study, which is also a library study, and the whole data source is a written documentation. This study has depicted the social communication occurred between Muslims and non-Muslims through the Qur'an. The Qur'an mentioned that Islam and Muslim are parts of a belief, but it also mentions about non-Muslim in a samawi scope, which are Yahudi, Nasrani and Ahl al-Kitab. The social communication between Muslims and non-Muslims is also detected in the Qur'an comprising topics like knowing each other, conducting a convention of peace, and a more lenient relationship with the Christians because of the same origin and an equivalent dialog with the believers of Ahl al-Kitab in a topic that doubts the Oneness of Allah the Almighty.
\end{abstract}

Abstrak: Kajian ini berangkat dari sebuah realita adanya komunikasi sosial dalam faktual tafsir fikih antara muslim dan non-muslim dalam al-Qur'an. Oleh karena itu, maka pertanyaan yang ingin dijawab adalah "bagaimana tafsir fikih menggambarkan komunikasi sosial antara penganut muslim dan non-muslim dalam al-Qur'an"? Kajian ini adalah studi kualitatif dengan jenis studi pustaka dan semua sumber data berbentuk dokumentasi tertulis. Kajian ini telah menggambarkan adanya komunikasi sosial penganut muslim dan non-muslim dalam al-Qur'an. Al-Qur'an menyebutkan Islam dan Muslim sebagai sebuah keyakinan, namun juga menyebut penganut non-muslim dalam lingkup samawi yaitu Yahudi, Nasrani dan Ahl al-Kitab. Komunikasi sosial antara muslim dan non-muslim yang terdeteksi dalam al-Qur'an mencakup saling mengenal, mengadakan perjanjian damai, hubungan yang lebih soft dengan Nasrani karena kesamaan asal dan dialog setara dengan penganut Ahl al-Kitab dalam topik tidak menyekutukan Allah SWT. sebagai tuhan.

Keywords: social communication, fiqh tafsîr, Qur’anic exegesis, Muslim, Non-Muslim 


\section{Introduction}

As social creatures, humans ${ }^{1}$ are absolutely demanded by the holy Qur'an to be good talkers since humans are the only creatures who are bestowed with the ability to talk. Speaking ability is the form of communication skill. Jalaluddin Rakhmad asserts that "communication is a must in every activity of humans." ${ }^{2}$ A research reported that $75 \%$ of people find that communication is the hardest thing to do during activities that involve communication skill ${ }^{3}$ although they can communicate effectively. ${ }^{4}$

Several literatures written in the old or contemporary documentation of the Qur'an tafsîr or interpretation have interpreted the verses of the Qur'an comprehensively and thoroughly started from surah al-Fâtihah up to al-Nâs. Those can be easily found in public libraries. ${ }^{5}$ These literatures have interpreted the verses of the Qur'an in various patterns and tendencies, such as fiqh, aqeedah, philosophy, literature, science and social community. The interpretation methods chosen are also varied, such as analytical (al-tahlîlî), thematic (al-maudhû̂$)$, comparative (al-muqârin) and global (al-ijmâlî). ${ }^{6}$ It seems that, as seen from various scientific studies, the study on social communication in fiqh interpretation, particularly an analytical study concerning Muslims and non-Muslims relation, which is written in the Qur'an, has not attracted the attention of any observers, activists, or researcher of Qur'an interpretation. It happened because the study of tafsîr/interpretation mostly revolves around theoretical scope and it rarely discusses implementational scope, especially social communication and fiqh interpretation.

The abovementioned arguments have led to an understanding that the study of fiqh interpretation needs to be more deeply studied, particularly the implementational scope of the verses of the Qur'an, which are related to the social communication between Muslims and non-Muslims, using analytical method so that the message can be conveyed comprehensively.

${ }^{1}$ Q.S. al-Rahmân/55: 4

${ }^{2}$ Jalaluddin Rakhmad, Psikologi Komunikasi (Bandung: Remaja Rosdakarya, 1996), p. vii.

${ }^{3}$ Sumarjo, "Ilmu Komunikasi Dalam Perspektif Al-Qur'an," in Jurnal Inovasi, Vol. 08, No. 01, 2011, p. 113-124.

${ }^{4}$ James G. Robbins and Barbara S. Jones, Komunikasi Yang Efektif, tr. Turman Sirait (Jakarta: CV Pedoman Ilmu Jaya, 1986), p. 3.

${ }^{5}$ There are three crucial phases of the Qur'an interpretation development; first: tafsîr in the era of Muhammad PBUH and his companions, second: tafsîr in the tabi'in era, and third: tafsîr in codification era. This codification era is started since the end of Bani Umayyah era and in the beginning of Bani Abbasiyyah era. Each era has its own method and peculiar way in interpreting the holy Qur'an. One weakness found in the history of tafsîr involves the first person that wrote the tafsîr of the Qur'an, which is arranged from the very first surah from al-Fâtihah up to an-Nâs, that is still debatable and is unconfirmed. However, this shortage does not diminish the fact that both printed and unprinted literatures of tafsîr have filled in the world Islamic libraries. Muhammad Husain al-Dzahabî, al-Tafsîr wa al-Mufassirûn, Vol. 1 (Kairo: Maktabah Wahbah, n.d.), p. 27-111. Subhî Shâlih, Mabâhitts fi 'Ulûm al-Qur'ân, ed. 29 (t.t.p.: Dâr al-'Ilmi li al-Malâyîn, 2000), p. 289.

${ }^{6}$ M. Alfatih Suryadilaga, Metodologi Ilmu Tafsir (Yogyakarta: Teras, 2010), p. 39. 
The following argument is related to the social typology of the society who live in Indonesia and is composed of numerous backgrounds, religions, cultures, ethnicities, and races. ${ }^{7}$ This study is expected to be a variable in communication and interaction within social scope so that moderation and the rahmatan li al-'âlamîn concept of Islam (bless for the whole universe) can be created.

The former studies or researches are closely connected to these theme and topic, like what has been conducted by Samsu who discusses the social interaction between Muslims and non-Muslims ${ }^{8}$ that highlights the verses of the Qur'an that are correlated with social interaction and no tafsîr/interpretation methodology is used. The same goes for the study conducted by Haidi Hajar Widagdo who analyzed the interaction between Muslims and non-Muslims based on the hadith perspective ${ }^{9}$ that focuses on the hadiths of the prophet as associated with social interaction. Another related study was conducted by Ali Imron who analyzed the social interaction between Muslims and non-Muslims in maqâshid al-syariah ${ }^{10}$ perspective within the range of the Islamic law. It focuses on the social interaction between Muslims and non-Muslims in fiqh law, which analyzed maqâshid al-syarîah. There is also a study written by Andi Rahman who discusses the relation of Muslims and non-Muslims in the history framework of the relation between Prophet Muhammad PBUH and Islamic ummah/Muslim people, Jews, or Christians ${ }^{11}$ which implicitly acknowledges the plurality of religions. In relation to the fiqh tafsîr study, there is study, which is written by Abdul Syukur, that emphasizes on the introduction to the Qur'an tafsîr pattern, ${ }^{12}$ theoretical pattern, and other models in interpreting the Qur'an. Another related study was conducted by Mhd Syahnan writed The Image of the Prophet and the Systematization of Ushul al-Fiqh: A Study of al-Shafi'i's Risâlah. ${ }^{13}$ There also a study written by Mhd Syahnan discuss and Critical Analysis of Sayyid Quthb's Principle Thought. ${ }^{14}$ However, none of those studies specifically tells about the fiqh studies such as "An Analytical Study of Social Communication between Muslims and non-Muslims in the Qur'an." Although the study

${ }^{7}$ Abd Mu'id Aris Shofa, "Memaknai Kembali Multikulturalisme Indonesia Dalam Bingkai Pancasila," in JPK, Jurnal Pancasila dan Kewarganegaraan, Vol. 1, No. 1, 2016, p. 34-40.

${ }^{8}$ Samsu, "Interaksi Sosial Muslim kepada Nonmuslim," in Jurnal Al-Munzir, Vol. 8, No. 2, 2015, p. 247-258

${ }^{9}$ Haidi Hajar Widagdo, "Interaksi Sosial Muslim dengan Non-Muslim Perspektif Hadis" (Thesis, Universitas Islam Negeri Sunan Kalijaga, 2011). p. 1-156

${ }^{10}$ Ali Imron, "Interaksi Sosial Muslim dan Non-Muslim Perspektif Maqâshid al-Syarîah," in http://repositori.uin-alauddin.ac.id/2216/, October 24, 2019

${ }^{11}$ Andi Rahman, "Relasi Muslim dan Non-Muslim," in http://journal.uinjkt.ac.id/ index. php/kordinat /article/view/6331, October 15, 2019.

${ }^{12}$ Abdul Syukur, "Mengenal Corak Tafsir al-Qurân," in El-Furqania: Jurnal Ushuluddin dan Ilmu-ilmu Keislaman, Vol. 1, No. 1, 2015, p. 84 - 104

${ }^{13}$ Mhd. Syahnan, "The Image of the Prophet and the Systematization of Ushul al-Fiqh: A Study of al-Shafi'i's Risâlah," in Jurnal Miqot, No. 103, 1998, p. 44-50.

${ }^{14}$ Mhd. Syahnan, "Islam as a System: A Critical Analysis of Sayyid Quthb's Principle Thought," in Analytica Islamica, Vol. 4, No. 1, 2002, pp. 45-57. 
reported by Samsu indeed informs about the social interaction between between Muslims and non-Muslims in the Qur'an, it is still general and has not specifically talked about fiqh tafsîr. Moreover, it has not reached out to the perspective used for responding to the method of interpreting the verses in the Qur'an, which becomes the basis of his argument and uses no method of interpretation. The comparison of the study will be broader if it is compared to Haidir's since his study is more specific and oriented to hadith. On the other hand, there will not be too many differences if it is compared to Ali Imron's study because it employs maqashid al-syariah (the objectives of sharia) perspective as the analytical approach. Whereas, Andi Rahman's study focuses more on three community entities, which are made as the objects that live side to side within the community as one entity, namely the people of Medina.

Understanding the aforementioned reasons, this study aims to fill in the already detected space. To make it more specific, one question that needs to be answered is "How is the analysis of the social communication, in fiqh tafsîr, between Muslims and non-Muslims as written in the Qur'an?" The question regarding social communication is very crucial since it is a new matter and a new topic of debate that is only confined in textual problem. To answer this question, this study employs an analytical perspective (al-tahlîli) across mufassirs (the author of the Qur'an tafsir) in understanding related verses. This study is categorized as a qualitative research and the type is library study, in which the whole data are provided in form of written literatures. The primary data are the verses of the Qur'an, which inform the social communication between Muslims and non-Muslims. Furthermore, this study also aims to do a deeper mapping on the serious power and effort in seeing the development of the study on the Qur'an and its tafsîr in a national scale.

\section{Results and Discussion}

\section{Social Communication in the Quran}

Communication cannot certainly be separated from human life since it is needed to organize the rules of relationship among humans. Ali Nurdin once stated that everything surrounds humans can be utilized to communicate with their environment, such as message, symbol, media, signal, password, information, news or even language. ${ }^{15}$ However, communication also emphasizes on the understanding of humans' behavior in producing, transforming, and interpreting the message for a certain goal. ${ }^{16}$

The term social communication is formed from two words, "communication" and

${ }^{15}$ Ali Nurdin, "Akar Komunikasi Dalam Al-Qurân," in Jurnal Kajian Komunikasi, Vol. 2, No. 1, 2014, p. $12-26$

${ }^{16}$ Ahmad Tamrin Sikumbang, "Teori Komunikasi: Pendekatan, Kerangka Analisis dan Perspektif," in Jurnal Analytica Islamica, Vol. 6, No. 1, 2017, p. 77-84 
"social". Communication is derived from Latin language, communicatio, and a root word communis, which means "the same". In this case, a communication can be considered as communicative if every party understands the language and the topic of the conversation. ${ }^{17}$ The word "communication" is not actually writen in the Qur'an, and it is already asserted by Efendi who said that "the Qur'an does not provide a specific explication about communication. ${ }^{18}$ Amir also affirms that there is no definition of communication or communication science, but those two sources depict some basic principles concerning communication. ${ }^{19}$ Even though the words "social communication" are not written in any of those sources, by quoting Nasution's opinion, Ali Nurdin said that the Qur'an has given some guideline ${ }^{20}$ regarding social problems in the community and the number of verses is greater than the verses informing about mahdhah, which is $228: 140^{21}$ in comparison. The word "social" is actually derived from a Latin language "sosio" that means "connected to the society." 22 The word "social", which is derived from Arabic language ijtimâ'iyyah, is understood as "matters that are related to the society."

These words have elucidated a conclusion that social communication is a conversation that occurs because of the use of the same language, which is understood by both parties, and the problems related to the order of the society. Further, social communication will be able to fulfill both the positive and negative emotional needs. The positive ones encompass the increasing mental health, acknowledging the meaning of humanity, sympathy, appreciation, and respect. The negative ones include the increasing feeling of proud, jealousy and hatred.

\section{The Position of Fiqh Tafsir in Qur'anic Interpretation Literatures}

Fiqh Tafsir is derived from the Arabic Language al-tafsîr al-fiqh, which consist of two words: al-tafsîr and al-fiqh. The word tafsîr is derived from the words fassara yufassiru tafsîran. ${ }^{24}$ The word al-fasru is understood as kasyfal-mughaththâ , which means "revealing

${ }^{17}$ Sumarjo, "Ilmu Komunikasi Dalam Al-Qurân, p. 113.

${ }^{18}$ Onong Uchjana Effendy, Ilmu Komunikasi: Teori dan Praktek (Bandung: Remaja Rosdakarya, 1999), p. 9.

${ }^{19}$ Mafri Amir, Etika Komunikasi Massa Dalam Pandangan Islam (Jakarta: Logos Wacana Ilmu, 1999), p. 11.

${ }^{20}$ One of those clues is the style of speaking, which is justified as a communication ethics, namely: a. Qaulan balîghan, Q.S. al-Nisâ'/4: 63. b. Qaulan maisûran, Q.S. Al-Isrâ/17: 28. c. Qaulan karîman, Q.S. al-Isrâ/17: 23. d. Qaulan ma'rûfan, Q.S. al-Ahzâb/33: 32. e. Qaulan sadîdan, Q.S. al-Nisâ'/4: 9. f. Qaulan layyinan, Q.S. Thâhâ/20: 44.

${ }^{21}$ Ali Nurdin, "Akar Komunikasi Dalam Al-Qurân," p. 12.

${ }^{22}$ The Definition of Social, in http://kbbi.web.id/sosial, August 29, 2016.

${ }^{23}$ Ahmad Mukhtâr 'Abd al-Hamîd 'Umar, Mu'jam al-Lughah al-Arabiyyah al-Mu'âshirah, Vol. I (n.p.: 'Âlam al-Kutub, 2008), p. 394.

${ }^{24}$ Muhammad bin Manzhûr, Lisân al-ÁArab, Vol. 5 (Beirut: Dâr al-Shâdir, 1414), p. 55. 
a hidden thing." ${ }^{25}$ Thus, from the etymological meaning, the word al-tafsîr is also known as al-bayân, al-taudhîh, al-kasyf or al-izhhâr. ${ }^{26}$ Respectively, these words mean information, explanation, uncovering, and showing. The definition based on etymology is then narrowed down into a more theoretical definition that is mentioned as "the discipline of study that is utilized to understand the holy book that was given by Allah the Almighty to Prophet Muhammad PBUH by explicating the content and socializing the laws." ${ }^{27}$ Based on the etymological definition, the word fiqh actually means "understand"; however, it is narrated as "a discipline of knowledge discussing the laws of syara' that contains "amaliah character and the sources are detailed theorems" based on the terminological definition. ${ }^{28}$

By comprehending the two definitions, at-tafsîr and al-fiqh, a conclusion can be drawn explaining that fiqh tafsîr is an in-depth study about the verses of the Qur'an, which focuses only on legal verses. To make it more tangible, Muhammad al-Khatîb declares that fiqh tafsîr is one of the Qur'an tafsîr patterns ${ }^{29}$ that dominate the problems of fiqh and its branches as well as differences of opinion and basic argumentation. As asserted by Baidan, the Qur'an tafsîr patterns comprise the color, direction, tendency of thoughts or certain ideas that dominate a work of tafsîr. ${ }^{30}$ Fiqh tafsîr is also wellknown as ahkam verses tafsîr and/or ahkam tafsîr.

Al-Dzahabî classifies the developmental phases of fiqh tafsîr in three periods. ${ }^{31}$ Those are the fiqh tafsîr period in the Prophet Muhammad PBUH era until fiqh madzhab (a school of thought), fiqh tafsîr that occurred after the taqlid era and fanaticism madzhab, and it was followed by various fiqh tafsîr as the impact of numerous Islamic sects. Abu Bakr alJashshâsh (w: $370 \mathrm{H}$ ), in his book entitled Ahkâm al-Qur'ân, is recorded as the first interpreter of fiqh tafsîr. Later, in the fifth century, Abû al-Hasan al-Thabarî who is also known as alKiyâ al-Harrâsa (w: $504 \mathrm{H}$ ) appeared as the writer of a book with the same title, A $\underline{h} k a ̂ m$ alQur'ân. In $543 \mathrm{H}$, another author appeared with his work that has, again, the same title.

${ }^{25}$ Muhammad Murtadhâ al-Zubaidî, Tâj al-Arûs min Jawâhir al-Qamûs, Vol. XII (n.p.: Dâr

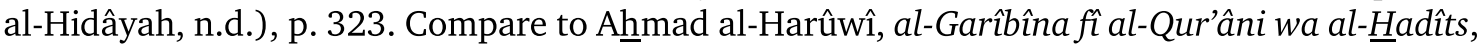
Vol. V (KSA: Maktabah Nazzâr Musthafâ al-Bâz, 1999), p. 1447.

${ }^{26}$ Shalâh 'Abd al-Fattâh al-Khâlidî, al-Tafsîr wa al-Ta'wîlf fî al-Qur'ân (Yordania: Dâr al-Nafâ'is, 1996), p. 41. Compare to 'Abîr bin 'Abdillah al-Na'îm, Qawấid al-Tarjîh al-Muta'alliqah bi al-Nashshi 'inda Ibn 'Ashûr fí Tafsîrih al-Tahrîr wa al-Tanwîr - Dirâsat Ta'shiliyah Tathbiqiyah (Riyadh: Dâr alTadmiriyah, 2015), p. 107.

${ }^{27}$ Fahd al-Rumî, Dirâsât fĩ 'Ulûm al-Qurân al-Karîm, Vol. XII (t.t.p.: t.p., 2003), p. 150.

${ }^{28}$ Zakaria al-Ansharî, al-Hudûd al-Anîqah wa at-Ta'rîfât al-Daqîqah (Beirut: Dâr al-Fikri alMu'âshir, 1411), p. 67. Compare to Aḥmad bin Hajar al-Haitamî, Tuhfah al-Muhthâj fí Syarh alMinhâj, Vol. I (Egypt: al-Maktabah al-Tijâriya al-Kubrâ, 1983), p. 20.

${ }^{29}$ Muhammad al-Khathîb, Taisîr al-Bayân li Ahkâm al-Qur'ân (Syiria: Dâr al-Nawâdir, 2012), p. 13.

${ }^{30}$ Nashruddin Baidan, Wawasan Baru Ilmu Tafsir, second edition (Yogyakarta: Pustaka Pelajar, 2005), p. 388.

${ }^{31}$ Muhammad Husain al-Dzahabî, al-Tafsîr wa al-Mufassirûn, Vol. II (Kairo: Maktabah Wahbah, n.d.), p. 321. 
He is Abu Bakr Ibn al-Arabî. In the sixth century, a book about fiqh tafsîr was published with the title al-Jâmi' li Ahkkâm al-Qur'ân. It was written by Abu 'Abdullâh al-Qurthubî (w: $671 \mathrm{H})$. Another book of fiqh tafsîr entitled al-Iklîlfî Isthinbâth al-Tanzîl made its appearance in 911 H, which was written by Jalâluddîn al-Suyûthî. Muhammad 'Ali al-Sayis (w: 1976) and Mannâ' Khalîl al-Qaththân (w: 1999), from the contemporary ulemas (Islamic scholars), have written a book with the same title Tafsîr Âyât al-Ahkkâm. ${ }^{32}$ Beside these two scholars, there was one named Muhammad 'Ali al-Shabûnî who has written a fiqh tafsîr entitled Rawâi' al-Bayân fî Tafsîr Âyâti al-Ahkkâm min al-Qur'ân."

Those scientific works have depicted fiqh tafsîr from the four majority of madzhabs and have presented fiqh tafsîr as a discipline of study that has been studied by many people and was popular among various levels of society. ${ }^{33}$ Fahd al-Rumî has affirmed that fiqh study grew in the beginning of the development of Islam, but the development of the branches of fiqh study has occurred in the second century. At the same time, the four majorities of madzhabs and fiqh madzhabs that have minority groups. ${ }^{34}$ The loyal believers of these minority and majority madzhabs reduced the legal verses tafsîr through rewriting and interpreting them based on the regulations of each madzhab in performing istinbath (revealing a theorem to determine a conclusion aiming to solve certain problem, especially concerning fiqh) on the law. However, it eventually was tainted and associated with fanaticism towards each madhhab. ${ }^{35}$ Although fiqh tafsîr appeared in the third century through products like numerous related literature until today, there is no real and comprehensive definition about fiqh tafsîrs that use literatures as the sources.

\section{Methodology of Qur'anic Exegesis}

Analytical method, which is called al-tahlîli in Arabic language, is one of the methodologies

\footnotetext{
${ }^{32}$ Mannâ' Khalîl al-Qaththân, Mabâhits fí Ulûm al-Qur'ân, third edition (Riyadh: Maktabah al-Ma'ârif li al-Nasyri wa al-Tauzî‘, 2000), p. 387.

${ }^{33}$ The diversity of madzhabs in fiqh and 'aqîdah has brought a significant impact on the development of fiqh tafsîr in various levels. From the historical view, fiqh tafsîr is actually deviated way too far from the original purpose, the concept of the revelation of the Qur'an, and the phase of the emergence of different madzhabs. These different madzhabs eventually significantly affected the emergence of fiqh tafsîr as driven by the believers of those madzhabs. Ahl al-Sunnah has several different fiqh tafsir $r$, but it is far from the term fanaticism. Zhahiriah has another fiqh tafsîr that prioritizes the zhahir's opinions regarding the verses of the Qur'an. Meanwhile, the khawarij community has a specific fiqh tafsîr reference. Syiah group also has a different fiqh tafsîr. All of these madzhabs have attempted to interpret the Qur'an, which then brought negative effects in form of madzhab fanaticism and even differed from the original meaning and the contentof the Qur'an. Muhammad Husain al-Dzahabî, al-Tafsîr wa al-Mufassirûn, Vol. II, p. 323.

${ }^{34}$ The madzhabs that have the minority of followers mentioned are al-Laits, Ibn Abî Lîlâ, al-Auzâîi, al-Thabarî, Abû Dâud al-Zhâhirî, al-Ja'farî, al-Zaidî dan al-Abadhî. Fahd al-Rumî, Ittijâhât al-Tafsîr fi al-Qarn al-Râbi' 'Asyarâ, Vol. II (KSA: t.p., 1986), p. 417.
} 
in interpreting the Qur'an. The emergence of al-tahlîlî as one of the methods is inseparable from the literature division of Qur'an tafsîr from various perspectives. Musâ'id al-Thayyâr, for instance, informs that the the divisions of tafsîr as seen from the methodology perspective are al-tahlîlî, al-ijmâlî, al-muqârin dan al-maudhûu'i ${ }^{36}$ The same thing is asserted from Baidan that among the Qur'an tafsîr methods, one of the existing one is al-tahlîli. ${ }^{37}$

Al-tahlîlî or analytic is derived from the sentence tahlîl al-yamîn, and it is then used in every level of conversation. ${ }^{38}$ The use is then specified by Ibrahîm Musthafâ who declared that al-tahlîli is "an analysis on a group of sentences by explaining the parts and functions." 39 Ahmad Mukhtâr adds up the function by "promoting analytical method as the basis in analyzing a study." 40 These varied opinions are then summarized in a more theoretical definition, which says that al-tahlîlî tafsîr is "interpreting the verses of the Qur'an based on the order of the surahs sequentially, verses, sentences, words, and revealing the values it contains, law, 'aqîdah or regulation, sharia, and social matter." 41

In relation to the previous definition, then the analytical method of tafsîr interprets the verses of the Qur'an by disclosing various aspects conveyed in every verse and surah sequentially as how they are arranged in the Qur'an, based on a mufassir's basic knowledge and tendency. Thus, almost all of the literatures of tafsîr employ amalytical tafsîr as the principal one for interpreting the verses of the Qur'an ${ }^{42}$ since analytical tafsîr aims to find out the sentences' purpose from the linguistic and sharia aspects, the relation between a sentence and another in the same or different verse, the role of qira'at (recitation) and its impact on the meaning, and others as the miracles of of the Qur'an. ${ }^{43}$ The completion towards the definition of this analytical tafsîr is understood as the mufassir's or interpreter's analysis according to his/her knowledge level as asserted by Abd al-Badi' an-Nirbânî. He stated that analytic is an operational stage of thought perfomed by logics in elaborating an object for generating a science. ${ }^{44}$

${ }^{35}$ Ibid. p, 417.

${ }^{36}$ Musâ'id al-Thayyâr, Fushûl fĩ Ushûl al-Tafsîr, Vol. II (n.p.: Dâr Ibn al-Jauzî, 1423), p. 113.

${ }^{37}$ Nashruddin Baidan, Wawasan Baru Ilmu Tafsir, p. 388.

${ }^{38}$ Muhammad Murtadhâ al-ㅂusainî, Tâj al-Arûsh min Jawâhir al-Qamûs, Vol. XXVIII (n.p.: Dâr al-Hidâyah, n.d.), p. 331.

${ }^{39}$ Ibrâhîm Musthafâ, et al., al-Mu'jam al-Wasîth, Vol. I (t.t.p.: Dâr al-Da'wah: n.d.), p. 194.

${ }^{40}$ Ahmad Mukhtâr, Mu'jam al-Lughah al-Arabiyyah al-Mu'âshirah, p. 550.

${ }^{41}$ Fadlu Hasan 'Abbâs, al-Tafsîr wa al-Mufassirûna Asâsiyâtuh wa Ittijâhâtuh wa Manâhijuh fì 'Ashri al-Hadis, Vol. I (Urdun: Dâr an-Nafâ'is li al-Nasyri wa al-Tauzî', 2016), p. 206.

${ }^{42}$ According to al-Farmawî, as quoted by Suryadilaga, the literatures of tafsîr that employs this analytical method is differentiated into tafsîr bi al-ma'tsûr, tafsîr bi al-ra'yî, tafsîr al-shûfi, tafsîr fiqhî, tafsîr falsafi, tafsîr al-adabî al-ijtimẩi. M. Alfatih Suryadilaga, Metodologi Ilmu Tafsir, p. 39.

${ }^{43}$ Musthafâ Muslim, Mabâhîts fí al-Tafsîr al-Maudhûî́, Vol. V (n.p.: Dâr al-Qalâm, 2005), p. 52.

44 'Abd al-Badi' al-Nirbânî, al-Jawânib al-Shautiyah fì Kutub al-Ihtijâj li al-Qirâ'ât, Vol. I (Damaskus: Dâr al-Ghautsânî, 2006), p. 310. 


\section{The Portrayal of Muslims and Non-Muslims in the Quran}

"Muslim" dan "Islam" are two words mentioned in the Qur'an that have different backgrounds of story, purposes, and connotations. ${ }^{45}$ In the Kamus Besar Bahasa Indonesia (KBBI), the word "Islam" is considered as "a school of belief that enacts a syariat or religious law for its follower or believer that must be implemented in their daily life." 46 The mentioned syariat comprises ritual implementation performed by the followers, such as syahadat (confession of faith), shalat (worship/prayer), fasting in the month of Ramadhan, zakat (alms-giving), and hajj (Islamic pilgrimage) ${ }^{47}$ for those who can afford it." ${ }^{18}$ The word "Islam" can also be defined as "acknowledging the truth verbally." It is differed

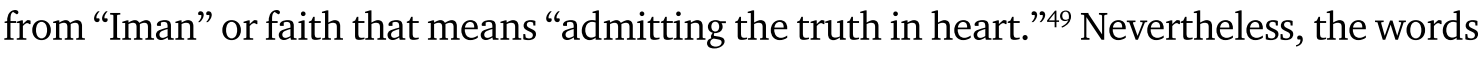
"Islam" and "faith" are practically used interchangeably because one of them has already represented the other, and they are derived from the same source. ${ }^{50}$ These dissimilarities are then considered as the dichotomy towards the fact that every Muslim is not always a mu'min (one who believes in Allah the Almighty), and every mukmin is certainly a Muslim. ${ }^{51}$

In a more theoretical definition, Sayyid Quthb defines the word "Islam" as "an absolute tawhid (belief in the unity of Allah) with the embedded specificity and obligation, which cannot be associated with syirk (belief in more than one God). ${ }^{52}$ This definition then orients towards the reality that "Islam" is perceived as the implementation of compliance, ${ }^{53}$

${ }^{45}$ The verse that disclose the word "Islam" in written in Q.S. al-Baqarah/2: 131 and Q.S. Âli"Imrân/3: 85. The word "Muslim" in: Q.S. al-Baqarah/2: 132, 133 and 136. Q.S. Âli-Imrân/3: 52, 64, 67, 80, 84 and 111. Q.S. al-Anbiyâ'/21: 14 and 108. Q.S. al-Naml/27: 81, Q.S. al-'Ankabût/ 29: 46, Q.S. al-Rûm/30: 53 and Q.S. al-Jîn/72: 14

${ }^{46}$ The definition of Islam, in http://kbbi.web.id/muslim, July 25, 2016.

${ }^{47}$ Islam encompasses five activities that must be implemented by every Muslim, and one or two activities are not suffice. It works the same for the word "faith" that cannot only be proven through particular activities, but it should be implemented comprehensively. Muhammad Jamâluddîn al-Qâsimî, Mahâsin al-Ta'wîl, Vol. I (Beirut: Dâr al-Kutub al-'Ilmiyah, 1418 ), p. 158.

${ }^{48}$ Muhammad bin Ismâî̂l al-Bukhârî, al-Jâmi‘ al-Musnad al-Shahîh, No. Hadîts. 8, Vol. VIII (n.p.: Dâr Thûq an-Najât, 1422), p. 11.

${ }^{49}$ Fakruddîn al-Râzî, Mafâtîh al-Ghaib, Vol. XXX (Beirut: Dâr Ihyâ al-Turâts al-'Arabî, 1420), p. 571.

${ }^{50}$ Wahbah al-Zuhailî, al-Tafsîr al-Munîr fì al-Aqîdah wa al-Syarî‘ah wa al-Manhaj, 2end edition, Vol. I (Damaskus: Dâr al-Fikri al-Mu'âshir, 1418), p. 318.

51 "Islam" and "Iman" has taken different places in every Muslim's heart, which can be analyzed with "the place of light within the sun." This analogy provides a comprehensive understanding that sun is a light and not every light is sun. To make the differences between Islam and faith embraced by every Muslim as an individual, the Qur'an has stated "qâlat al-a'râbu âmannâ qul lam tukminû wa lâkin qûlû aslamnâ (Q.S. al-Hujurât/49: 14). Abû Ishâq Ahmad al-Tsa'labî, al-Kasf wa al-Bayân 'an Tafsîr al-Qurân, Vol. I (Jeddah (KSA): Dâr al-Tafsîr, 2015), p. 145.

${ }^{52}$ Sayyid Quthb bin Ibrâhîm al-Syatibî, Fî Zhilâl al-Qur'ân, Vol. I (Beirut: Dâr al-Syurûq, 1412), p. 412.

${ }^{53}$ Sirâjuddîn 'Umar, Al-Lubâb fì 'Ulûm al-Kitâb, Vol. V (Beirut: Dâr al-Kutub al-'Ilmiyah, 1998), p. 106. 
by being submissive, objective, and obedient through system, method, and law. ${ }^{54}$

The word "Muslim" is understood as "the believers of Islam." ${ }^{55}$ Sayyid Quthb explicated in details that Muslims are "people who only worship Allah, are submissive to Allah, and do not help each other to do polytheism." ${ }^{n 6}$ Related to the whole human race, al-Khathîb proclaims that those who believe in the Risâlah (a summary of religious prescription in Islam) brought by the prophet and messenger of Allah without altering or replacing it are the people who are acknowledged as Muslims. ${ }^{57}$ Hence, Islam and Muslims are not only revolving around shariat or Islamic law, the followers of the shariat, and the ummah or the Islamic community who believe in Prophet Muhammad PBUH particularly, but they also encompass the shariat and the followers of the earlier prophets. ${ }^{58}$ As a religion and belief, Islam is also the preaching of the earlier prophets and messengers of Allah, ${ }^{59}$ Islam also commands the Muslims' lineage or descendant to perform all Islamic principles comprehensively, to have no other beliefs, and also to eventually die as mu'mins. The Muslims' characteristics mentioned above are the characteristics that distinguish Muslims and other human beings who embrace other ideologies. The realization towards the phases of the perfect or complete level as a Muslim is an urgent thing to do. It is inseparable from the verbal confession as Muslims, but it is not directly proportional to the realization of those phases as the form of the standardized procedure to be a complete Muslim.

The Qur'an, which has clearly documented the words Islam and Muslim in several narration of verses, has not narrated the words Non-Muslim or ghair muslim. In mentioning non-Muslim, the Qur'an discloses the community existence, belief, and ritual activities performed by ghair muslim (non-Muslim) in form of exclamation/persuasion or open dialogue. Non-Muslim communities that are revealed by the Qur'an are essentially in conformity with the Islamic preaching mission of Prophet Muhammad PBUH at certain era in Mecca and Medina. The ghair muslim communities that were directly involved in the Prophet Muhammad's (PBUH) mission are the musyrik (the people in Mecca who disobeyed

${ }^{54}$ Sayyid Quthb, Fî Zhilâl al-Qur'ân, p. 423.

55 "Pengertian Muslim," in http://kbbi.web.id/muslim, July 25, 2016.

${ }^{56}$ Sayyid Quthb, Fî Zhilâl al-Qur'ân, p. 407.

${ }^{57}$ 'Abd Karîm Yûnus al-Khathîb, al-Tafsîr al-Qur'ânî li al-Qur'ân, Vol. II (Kairo: Dâr al-Fikri al'Arabî, n.d.), p. 515.

${ }^{58}$ Browsing through the journey of Islam as a faith, belief, and religion, Muslims need to see and study the verses of the Qur'an that reveal this noble religion's journey and history through the Risâlah brought by the prophet and messengers of Allah. Muslims must have a faith that Islam is the religion set by Allah the Almighty for the human beings through the prophets and messengers who are sent down by Allah. It is in line with the illustration in which Prophet Ibrahim AS asked and beg to make his family and children converted to Islam. Prophet Ya'qub also begs for the similar thing and commands his childrensn and descendants to convert to Islam and to eventually die as mu'mins. See Q.S. al-Baqarah/ 2: 128, 131, Q.S. Âli-'Imrân/3: 67 and Q.S. alBaqarah/2: 132

${ }^{59}$ Wahbah al-Zuhailî, al-Tafsîr al-Munîr fî al-'Aqîdah wa al-Syarî‘'ah wa al-Manhaj, p. 319. 
Allah) in the pre hijrah era (the migration of Prophet Muhammad and his followers), Jews, Christians, and Ahl Kitâb (the people of Medina) after hijrah era.

The musyrik is the justification embedded on the people who live in Mecca. At that time, the majority of them believed in animism and performed rituals as the worshipper of animate or inanimate objects. This understanding has been asserted by al-Thabarî who declared that musyriks are the Arabic people who worship sculptures and rocks, who also do not have any religious or holy book. ${ }^{60}$ The word musyrik is derived from the Arabic language al-syirk that means kurf (those who deny the truth of Islam) ${ }^{61}$ since they performed rituals of idolizing others beside Allah the Almighty. ${ }^{62}$ Whereas, Sayyid Thanthâwi opined that the word musyrik is derived from the Arabic word al-isyrâk $k^{63}$ which is interpreted as "set an object for idolatry among you and among others beside you." Therefore, the religious groups who believe in polytheism or dualism of God, and put their object of idolatry next to Allah the Almighty, are also included in syirk category. ${ }^{64}$ A stronger definition explains that "musyrik" is "the people who equalize other things with God and claim them as their god." 65 Observing the various interpretations, then the word musyrik is actually attached to individuals who are aware or unaware and deliberately or undeliberately performed rituals by worshipping others beside Allah the Almighty as the only God.

The Qur'an also has exposed that the terminologies, such as andâd, âlihah, thagût and $a r b a \hat{b} b^{66}$ are synonymous to and are the forms of syirk; including the words al-syirk and musyrik. The meaning and objective of the words musyrik, musyrikin or musyrikât written in the Qur'an are the worhisppers of animate or inanimate objects, not the Jews and Christian community because the Qur'an address these two groups using the terminology Ahl al-Kitâb. A number of beliefs emerged in the current era shows particular rituals or religious activity that is worshipping objects, beside other types of beliefs. Thus, the use

${ }^{60}$ Muhammad bin Jarîr al-Thabarî, Jâmi' al-Bayân fí Ta'wîl al-Qurân, Vol. IX (t.t.p.: Mu'assasah al-Risâlah, 2000), p. 573.

${ }^{61}$ Zainuddîn al-Râzî, Mukhtâr al-Shahâh, Vol. V (Beirut: al-Maktabah al-Ashriyah, 1999), p. 164.

${ }^{62}$ Muhammad bin Manzhûr, Lisân al-Arab, Vol. X, p. 449.

${ }^{63}$ Sayyid Thanthâwî has an argument againts the dialogue mentioned in the Quran that involved Luqman and his son; Allah said: "(And (remember) when Luqman said unto his son) Salam, (when he was exhorting him) when he was enjoining him to do good and forbidding him to engage in evil: (O my dear son! Ascribe no partners unto Allah. To ascribe partners (unto Him) is a tremendous wrong) it is a great sin which is punished by Allah." ${ }^{63}$. (Q.S. Luqmân/31: 13). Muhammad Sayyid Thanthâwî, al-Tafsîr al-Washîth li al-Qurân al-Karîm, Vol. I (Kairo: Dâr alNahdhah Misir li al-Thibâ'ah wa al-Nasyri wa al-Tauzî́, 1998), p. 488.

${ }^{64}$ Ibid., p. 488.

${ }^{65}$ Isma'îl Hamda al-Jauharî, al-Shahhâh Tâj al-Lughah wa Shahâh al-'Arabiyah, Vol. IV (Beirut: Dâr al-'Ilmi li al-Malâyîn, 1987), p. 1593.

${ }^{66}$ The word Andâd is a plural form, and the singular form is an-niddu that is translated as "alike." The Quran mentions this word in its verses, which is "falâ taj'alu lillâhi andâdan wa antum ta'lamûna," (Q.S. al-Baqarah/2: 22). The word Âlihah is also a plural form and its mufrad or singular form is Ilâhah. This word has become an expression given by the Arabic community 
of the word musyrik that appeared in the pre Islam era still has relevant implementations for today's era.

Jewish people are the members of another non-Muslim group, whom are frequently mentioned in many verses of the Qur'an. Jews are known as the members of the community in Medina and Khaibar when Prophet Muhammad PBUH did hijrah. This Jewish community is polarized in several major ethnicity groups. Some of them are Bani Quiniqa, Bani Nadhîr, Bani Quraizhah, Bani Musthaliq and other small Jewish called Taimâ, Fadâk dan Wadi al-Qurâ. ${ }^{67}$ These Jewish groups which live in and around Medina and Khaibar are recorded in the history as the Jewish group that saved themselves from the Roman authority, which has taken control over the old Kingdom of Israel in Palestine. The word "Jew" is attributed to Bani Israel that has been admitted as the ummah of Prophet Musa A.S. Bani Israel has migrated to Egypt and has become one of the communities of Egypt that lived for several centuries before they moved back to Palestine under the leadership of Prophet Musa a.s. This Israel clan is also identified as the Hebrew people or nation as the justification towards the lineage of Prophet Ibrahim a.s. ${ }^{68}$ It is named as the Jews because they once seeked for forgiveness of Allah. This term is then continued to address Jewish people who either did repentance or not. ${ }^{69}$

Christian is also a non-Muslim community stated in the Qur'an and is detected as one of the communities who lived around Medina in the years prior to the hijrah when Prophet Muhammad PBUH moved to Medina. The word "Nasrani" (the Christian) is derived from the Arabic language nashrânî, which is the singular form of nashârâ that refers to the name of a village (nashrân) ${ }^{70}$ in an area called Syam. The term nashrânî is then continued

before the Islamic era for the objects they worship, which are made from rocks and woods. The Quran wrote the sentence Âlihah in the verse "wa yadzaruka wa âlihataka," (Q.S. al-A'râf/7: 127). Thagut in mufrad form (single) and the jama' (plural) form is Thawâgits. This word is used to refer to any object of idolatry other than Allah the Almighty, and every religious leader of animism. There are four types of interpretation made for the word Thagût as written in the Qur'an. Those are the object for idolatry, satan or devil, witch, and Ahl al-Kitâb. The Qur'an has revealed this word in it verse "yu'minûna bi al-jibti wa al-thagût" (Q.S. al-Nisâ'/4: 51). The word Arbâb means "religious leader" for both ulema (Islamic scholar) and ustadz (teacher) who are considered as the leaders who lead to perversity or distortion of Islam like claiming an object as halal (acceptable according to Muslim Law), but it is actually prohibited by Allah the Almighty, and vice versa. The word Arbâb is written in the verse "ittakhadzû akhbârahum wa ruhbânahum" (Q.S. alTaubah/9: 31). Muhammad Murtadhâ al-Husainî, Tâj al-Arûsh min Jawâhir al-Qamûs, p. 216. Muhammad al-Azharî, Tahdzîb al-Lughah, Vol. VI (Beirut: Dâr Ihyâ' al-Turâts al-'Arabî, 2001), p. 224. Muhammad bin Manzhûr, Lisân al-Arab, Vol. VIII, p. 444. Compare to Muhammad bin Jarîr al-Thabarî, Jâmi' al-Bayân fî Ta'wîl al-Qurân, Vol. XIV, p. 209.

${ }^{67}$ Ahmad Golouse, al-Sîrah al-Nabawiyah wa al-Da'wah fí 'Ahd al-Madnî (t.t.p.: Mu'assasah al-Risâlah li al-Thibâ'ah wa al-Nasyri wa al-Tauzî̀, 2004), p. 33.

${ }^{68}$ Ahmad Mukhtâr, Mu'jam al-Lughah al-'Arabiyah al-Mu'âshirah, p. 231.

${ }^{69}$ Muhammad al-Anbarî, al-Zâhir fí Ma'ânia al-Kalimât al-Nâs, Vol. II (Beirut: Mu'assasah al-Risâlah: 1992), p. 214. Compare to Muhammad al-Ba'lî, al-Mathla' 'alâ Alfâzh al-Maqna', Vol. I (t.t.p.: Maktabah al-Sawâdî, 2003), p. 262.

${ }^{70}$ Ibid., p. 263 
to be used to address this religion and the followers. ${ }^{71}$ Muhammad Ruwâs Qal'âjî and Hâmid Shâdiq Qanbî informed that the word "nasrani" is translated from English into the word Christian. ${ }^{72}$ Ahmad Mukhtâr claims that nashrânî is the singular form of nashârâ, and this term is used to address those who believed in the religion of Isa al-Masîh. ${ }^{73}$ Mostly, the words nashrânî and nashârâ are written next to or in the same context where the word yahûdî is also mentioned in the Qur'an. Those words are written in a wrong orientation that lead to the perversity perfomed by these two communities.

The Muslim community who lived during the era of Prophet Muhammad PBUH had a great favor towards the Christian community related to the conflict between two kingdoms that involved two nations and two ideologies at that time named Nasrani (ahl al-kitâb) and Majusi (fire-worshipper, animism). ${ }^{74}$ Nasrani was represented by the Rum people and Majusi was represented by the Persians. ${ }^{75}$ The relation between Islam and Christian during the time when Prophet Muhammad performed Islamic preaching in Mecca was actually slightly better, ${ }^{76}$ and even a little bit emotional. ${ }^{77}$

The Jews and Christians were clearly inscribed in the verse of the Quran. The examples are the words of Allah "wa qâlat an-nashârâ al-masîhu ibnu Allah,"78 and "mâ kâna ibrâhîmu

${ }^{71}$ Ahmad al-Fayyûmî, al-Mishbâh al-Munîr fí Gharîb al-Syarh al-Kabîr, Vol. 2 (Beirut: al-Maktabah al-'Ilmiyyah, n.d.), p. 607.

${ }^{72}$ Muhammad Ruwâs Qal'âjî, et al., Mu'jam Lughah al-Fuqahâ', Vol. I (t.t.p.: Dâr al-Nafâ'isy li al-Thibâ'ah wa al-Nasyri, 1988), p. 480.

${ }^{73}$ Ahmad Mukhtâr, Mu'jam al-Lughah al-Arabiyyah al-Mu'âshirah, p. 2221.

${ }^{74}$ The Christian is included in the Ahl al-Kitab community beside the Jew. However, it is different from Majusi, which is obviously mentioned in the Quran as thâ'ifataini (two communities). If the Quran mentions tsalâtsa thawâ'if (three communities), it means that the Majusi community is involved. Q.S. al-An'âm/6: 156. Abû Bakar al-Jashshâsh, Ahkâm al-Qur'ân, Vol. IV (Beirut: Dâr al-Kutub al-'Ilmiyah, 1994), p. 198.

${ }^{75}$ This action of taking favor is written in the Quran, Q.S. al-Rûm/30: 1-2. 'Abdullâh bin Qutaibah, Ta'wîl Musykil al-Qur'ân, Vol. I (Beirut: Dâr al-Kutub al-'Ilmiyah, n.d.), p. 239.

${ }^{76}$ Some of the emotional connections are the attestation of the Quran as written in Q.S alMâ'idah/5: 82 that mention the characteristics of Islam and the Jews relation as well as Islam and Christians. The Jews have an unbending relation with Islam. Vice versa, the Christian has a better relationship. The Christians have known the characteristics of Prophet Muhammad PBUH as they are mentioned in the Bible; the same things written in Q.S. al-Baqarah/2: 146. A Christian priest named Buhairah had protected Prophet Muhammad PBUH during his trip for trading in South Bushra Syam city (Syria), which was led by the prophet's uncle, Abu Thalib. Abd al-Mâlik bin Hisyâm, al-Sîrah al-Nabawiyah, Vol. I (Mesir: Syirkah Maktabah wa Mathba'ah Musthafâ alBâb al-Halâbî wa Aulâdih, 1955), p. 180.

${ }^{77}$ As the King who was a Christian, Najasyi, who protected the companions of the prophet during the hijrah known as the Hijrah Habsyah I and II. This act of protection was very emotional because the Quran recited by the prophet's companions told a story about Prophet Isya A.S. The story was confirmed and was in line with the context in the Bible they hold on to. Ibid., Vol. I, p. 333.

${ }^{78}$ Q.S. al-Taubah/9: 30. 
yahudiyyan walâ nashrâniyyan wa lâkin kâna hanîfan musliman,"79 "and the Christian people say: "al-Masih is the son of Allah." "Ibrahim is not a Jewish and (also) not a Christian, but he is an honest person who has surrendered (to Allah)."

Ahl al-Kitab is the fourth non-Muslim group that is frequently mentioned in the Quran. This group consists of Jews and Christian community that performed their rituals based on Tawrat and Injil (Gospel). ${ }^{80}$ Muhammad 'Amîm informs a broader scope about Ahl Kitab by saying "Jews are generally known from Bani Israel and Christians, who believe in samawi or Abrahamic religions, and those who have the descended holy books such as the Scrolls of Ibrahim/Abraham, the Tawrat/Torah of Musa, the Zabur of Dawud, and the Gospel of Isa 'alaihim as-salâm." ${ }^{81}$ Moreover, Imam Syâfi'i opines that the Ahl alKitab community did not exist anymore right after Prophet Muhammad PBUH was chosen to be the prophet and messenger of Allah. The people who converted to and believe in this belief after the revelation of the Qur'an should have accepted Islam as their belief; thus, they must also pay jizyah (tax) as what the musyrik people did. ${ }^{82}$ Hence, according to Imam Syâfi'i's argument above, if Ahl al-Kitab was already not approved in the era of Prophet Muhammad, then the same discernment should also be applied to other followers and beliefs that have been transformed into various sects as well as the followers of the modern animism that have been labelled with various religions and beliefs in the current era.

Al-Shabi'în and al-Majusi are other non-Muslim groups that are documented in the Quran..$^{83} \mathrm{Al}$-Shabiîn refers to a group that denies the existence of "the Creator," and alMajûsî si the fire-worshipper. ${ }^{84}$ By taking a closer look on the meaning of al-Shabi'în and al-Majûsî, the term 'ritual practice' that is performed by some individuals of the millennial generation appears as its association. These communities are known with reduced names, such as the atheism ideology believed by those who deny the existence of God (the Creator), and other Buddhist, Confucius, that involves fire in their religious ritual practice.

\section{Muslim and Non-Muslim Social Communication in Fiqh Tafsir}

Tafsîr can generally be defined as the product of ijtihad (efforts) of the ulemas who possess adequate potentials and knowledge in interpreting the Quran. Muhrif Saqâ says that the interpretation of the Qur'an is merely an ijtihad for explaining and explicating

${ }^{79}$ Q.S. Âli-'Imrân/3: 67.

${ }^{80}$ Jamaluddîn bin al-Mubarrad, al-Dur al-Naqî fí Syarh Alfâzh al-Khurqî, Vol. III (JeddahKSA: Dâr al-Mujtama' li an-Nasyri wa al-Tauzî‘, 1991), p. 626.

${ }^{81}$ Muhammad 'Amîm al-Ihnsân al-Mujaddî, al-Ta'rifât al-Fikhiyah, Vol. I (Beirut: Dâr al-Kutub al-'Ilmiyah, 2003), p. 29.

${ }^{82}$ Muhammad bin al-Thâhir bin 'Ashûr, al-Tahrîr wa al-Tanwîr, Vol. VI, p. 120.

${ }^{83}$ Q.S. al-Baqarah/2: 62, Q.S. al-Mâ'idah/5: 69 dan Q.S. al-Hâj/22: 17.

${ }^{84}$ 'Abd Karîm Yûnus al-Khathîb, al-Tafsîr al-Qur'ânî li al-Qur'ân, Vol. IX, p. 1002. 
the content of the Qur'an by taking the rules of the tafsîr study ${ }^{85}$ into account. Suryadilaga has also stated the same thing as what has been narrated in the Qur'an that is introduced as hudan (guide), but in another occasion, it is introduced as al-furqân (distinguisher). The effort to understand the Qur'an accurately is identified as the term "tafsîr."

As pointed out in the explanation of community authority above, the social communication between Muslim and non-Muslim that was depicted in the verses of the Qur'an, was then understood as the authoritative tafsîr literatures, and produced the fiqh tafsîr resume as described in the following points:

\section{Social Communication Engaged for Mutual Recognition}

The command given to human beings to know each other is the main social communication

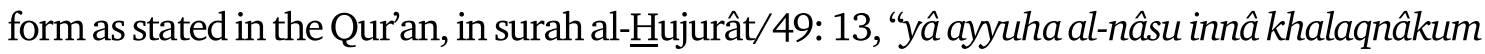
min dzakarin wa untsâ wa ja'alnâkum syu'ûban wa qabâ'ila lita'ârafû inna akramakum 'inda Allâhi atqâkum inna Allâha 'alîmun khabîr." Ibn al-Jauzî affirms that the verse was sent down after the conquest of Mecca, precisely right after Adhan (Islamic call for prayer) was chanted by Bilal bin Rabah from the top of $K a{ }^{\prime} b a h .{ }^{86}$

This verse confirms the origin of human beings, the males and females, Prophet Adam a.s. and Hawa, and humans then underwent a change or metamorphism among different tribes and nations. Ibn 'Athiyah delivers two interpretations with two indications as shown in the sentence "dzakarin wa untsâ," first: the ones mentioned previously are Adam a.s. and Hawa, then the indication tells as if Allah the Almighty says "...Him Who created you of a single soul Adam and from it created its mate Eve Hawwâ."Second: dzakarin wa untsâ can also be defined as "the name for something," therefore, it indicates as if Allah the Almighty says "Verily We created man the species from a drop of mixed fluid from a mixture that is from the seminal fluid of the man and the ovarian fluid of the woman..." 87

The word "lita'ârafû" is the keyword of social communication that appears in this verse. The word al-ta'âruf is the argumentation that is accompanied with the essential value on a creation with the nation and ethnicity background, ${ }^{88}$ which is also used to

${ }^{85}$ Saqa al-Jabbâr, et al., al-Tafsîr wa I'jâz al-'Tlmifial-Qur'ân al-Karîm (Damaskus: Dâr Muhammad Amîn, 2010), p. 97.

${ }^{86}$ 'Abd Rahman bin al-Jauzî, Dzâd al-Masîr fí 'Ilm al-Tafsîr, Vol. IV (Beirut: Dâr al-Kitâb al'Arabî, 1422 H), p. 152.

${ }^{87}$ Muhammad bin 'Athiyah al-Andalûsî, al-Muharrar al-Wajîz fì Tafsîr al-Kitâb al-'Azîz, Vol. V (Beirut: Dâr al-Kutub al-'Ilmiyah, 1422 H ), p. 152.

${ }^{88}$ Human classification based on the origin, nation, ethnicity, and family as written in the Arabic terminology with six names, namely: al-sya'bu, al-qabîlah, al-imârah, al-butûn, al-afkhâdz and al-fashîlah. Al-Baidhâwî made an analogy: Khuzaimah was chosen for taking the role of sya'b, Kinânah for qabîlah, Quraiys for 'imârah, Qushai for butun, Hasyîm for fakhz and 'Abbâs for fashîlah. There are only three of these six terminologies that are shown in the Qur'an, namely al-

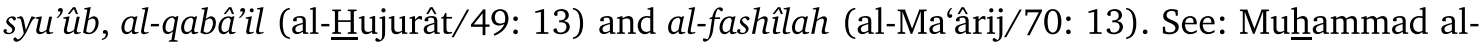


avoid fanaticism. ${ }^{89}$ Whereas, the sentence syû́ban wa qabâ'ila was interpreted by Muhammad Makki into "adjusting to each other" in form of the search of adjustment between one and another so that they will recognize each other. ${ }^{90}$ On the other side, al-Zuhailî explains the reason of the human creation in more details by explicating the background of different nations, ethnicities, and families. They are created to know, communicate, interact, and cooperate with each other; and not to break the relation, create enemies, brag, do ghibah/ gossiping that will lead to debates and hostility as well as to brag about nasab and clan. ${ }^{91}$

Recognizing nasab in Islamic teaching as the "sharia demands" category as asserted by al-Sa'dî̀ ${ }^{92}$ is an essential part to be promoted by this verse. According to Abû Bakr alJazâirî, nasab is a form of the nation, ethnicity, big family, and spouse creation in order to create a conducive social environment indicated by helping and cooperating with each other. ${ }^{93}$ Fanaticism in religion, nation, and ethnicity are covered in this verse through the narration "innâ akramakum 'inda Allâhi atqâkum". According to al-Khathîb, the narration of this sentence is also the act of straightening up the misleading understanding that has been contaminated and is laid within humans' soul in form of material and spiritual phenomena among groups. It is also necessary to embed the ingenious reasoning in terms of the proportion in looking at every human.

The social communication presented in this verse is a form of social communication that can be perfomed between a Muslim and a non-Muslim, and even a Muslim and all humans using the law and ethics as the main principles. This argumentation arises based on the textual verse in the sentence "yâ ayyuha al-nâs". Al-Khatîb states that this verse is sent down to the people of Mecca who were still musyrik, but on the other side, the people who listened to and implemented it were the Muslims. Al-Khathîb kept conveying his interpretation by mentioning that the "al-nâs" (human) refer to the Muslims and nonMuslims who are admitted as "the brothers and sisters in humanity" because they were created from one body, Adam A.S. ${ }^{94}$ Ibn 'Ashûr gave an additional information that the implementation of this verse is diverged from the obligation to do global communication

Amîn al-Mukhtâr al-Syinqithî, Adhwâ al-Bayân fi Îdhâh al-Qurân bi al-Qurân, Vol. III (Beirut: Dâr-al-Fikri, 1995), p. 45. Compare to Nâshiruddîn al-Baidhâwî, Anwâr al-Tanzîl wa Asrâr alTa'wîl, Vol. V (Beirut: Dâr Ihyâ al-Turâts al-'Arabî, 1418 ), p. 137.

${ }^{89}$ Muhammad al-Amîn al-Mukhtâr al-Syinqithî, Adhwâ al-Bayân fî Îdhâh al-Qurân bi alQurân, Vol .III, p. 45.

${ }^{90}$ Muhammad Makkî, al-Hidâyah ilâ Bulûg al-Nihâyah fí Ilm Ma'ânia al-Qurân wa Tafsîrih wa Ahkkâmih wa Jumal min Funûni 'Ulûmih, Vol. XI (Syarjah: Jâmi'ah al-Syâriqah, 2008), p. 7010.

${ }^{91}$ Wahbah al-Zuhailî, al-Tafsîr al-Munîr fí al-Aqîdah wa al-Syarî’ah wa al-Manhaj, p. 266.

92 'Abdurrahmân al-Sa'dî, Taisîr Karîm al-Raḩmân fî Tafsîr Kalâm al-Manân, Vol. I, (n.p.: Mu'assasah al-Risâlah, 2000), p. 802.

${ }^{93}$ Abû Bakr al-Jazâirî, Aysar al-Tafâsîr li Kalâm al-Aliyy al-Kabîr, Vol. V (Madînah al-Munawwarah: Maktabah al-'Ulûm wa al-Hukm, 2003), p. 131.

94 'Abd Karîm Yûnus al-Khatîb, al-Tafsîr al-Qurânî li al-Qurân, Vol. XIII, p. 452. 
and interaction to the realization that must be executed by each individual since each tribe possesses the basic fanaticism towards its tribe..$^{95}$

\section{Social Communication Through the Peace Treaty Arrangement}

A peace treaty is the social communication that had been performed by the prophet with the non-Muslim parties, such as the Jews, Christians, inland Arabic tribes, and the musyrik community in Mecca. The biggest rival in the history of the prophet's Islamic preaching is the musyrik community in Mecca before the invasion era (fathu Makkah), who once sat down next to the prophet in discussing the peace treaty known as Hudaibiah agreement. Social communication was reaching no where when the Mecca musrik community violated the points of the agreement as written in surah al-Taubah/9, verse 1 . Allah the Almighty says: "barâat min Allâhi wa rasûlihi ila al-ladzîna 'âhadtum min al-musrikîna." (This is a declaration of immunity from God and His Messenger to reach the idolaters with whom you made a pact). The word barâah written in the verse is the synonym of the word takhallasha, which is translated into complete, clean and clear. ${ }^{96} \mathrm{Al}$-Ahd and al-mu'ahadah is "the agreement that is arranged by two parties, which have prevailing regulations." The subjects of the peace treaty mentioned in this verse are Allah and the Messengers of Allah as well as Allah and the musyrik group in Mecca.

This verse also discloses the behavior of the musyrik group in Mecca who violated the agreement without any convern from the other party, and it was validated as the annulment of agreement. The consequence of violating the agreement that automatically led to the annulment was then followed up by the realization that Allah and His Messengers had the "clean and clear "concept with the points of the agreement, ${ }^{97}$ and so casted the command to annul the agreement. ${ }^{98}$ Thus, the Muslims (the prophet and his companions) were allowed to do anything, which was forbidden as stated in the peace treaty. Al-Razî has affirmed that the one-sided annulment of agreement should be based on three things. ${ }^{99}$ Those are the content of agreement that has been violated by one of the parties, certain time period that has been agreed upon until Allah the Almighty sent His commands to annul it, and the end of the limit time as agreed.

${ }^{95}$ Muhammad bin al-Thâhir bin 'Ashûr, al-Tahrîr wa al-Tanwîr Vol. XXVI, p. 258.

96'Abd Rahmân al-Tsa'âlibî, al-Jawâhir al-Hisân fî Tafsîr al-Qurân, Vol. III (Beirut: Dâr Ihyâ' al-Turâts al-'Arabî, 1418 H), p. 161.

${ }^{97}$ Fakhruddîn al-Razî, Mafâtîh al-Ghaib, Vol. XV, p. 523.

${ }^{98}$ Ahmad al-Marâghî, Tafsîr al-Marâghî, Vol. X (Mesir: Musthafâ al-Bâb al-Hâlabî, 1942), h. 54 .

${ }^{99} I b i d .$, p. 523. 


\section{Social Communication in a "Soft" Relationship Form with the Christians}

The Jews and Christians are non-Muslim communities that inhabited the Medina city who live socially close to Prophet Muhammad PBUH and his companions. These two communities had the same mission and vision, which was opposing Islam as a religion, Muhammad PBUH as the prophet and messenger of Allah and his companions as the followers of Islam and Muhammad PBUH. In spreading hatred and confrontation, the Jews community was harsher, crueler, and more cunning than the Christian community. The Christian community that lived around Medina and Arabian Peninsula didn't do what the Jews community did. They surprisingly had the tendency to "protect" the prophet and his followers. One of the examples was Buhairah who asked Abu Thâlib to go back to Mecca for protecting Muhammad, when he was a teenager, who was joining the kafila (a group of merchants) that was heading to Syria. Another instance was the protection given by al-Najasyî (the Christian king of Habsyah kingdom) to the companions of the prophet in the first and second hijra history. The Holy Quran has revealed the treatments of these two communities and the musyrik toward the mu'min in Q.S. al-Mâ'idah/5: 82, "latajidanna asyadda al-nâsi 'adâwat li alladzîna âmanû al-yahûda wa al-ladzîna asyrakû wa latajidanna aqrabahum mawaddat li al-ladzîna âmanû al-ladîna qâlû innâ nashârâ dzâlika bi anna minhum qissîsîna wa ruhbân wa annahum lâyastakbirûn". (You O Muhammad (s) will truly find the most hostile of people to those who believe to be the Jews and the idolaters of Mecca because of the intensity of their disbelief ignorance and utter preoccupation with following whims; and you will truly find the nearest of them in love to those who believe to be those who say 'Verily we are Christians'; that nearness of theirs in love to the believers is because some of them are priests scholars and monks devout worshippers and because they are not disdainful of following the truth as the Jews and the Meccans are.)

The keywords in this verse are 'adâwah dan mawaddah. As what Akhmad Mukhtâr said, 'adâwah is "hatred and hostility." ${ }^{100}$ It even led to the realization of action. ${ }^{101}$ The word mawaddah means "friendship that leads to sisterhood or brotherhood"102 and "affection"103 based on the Andoze understanding. Akhmad Mukhtâr explains that the word mawaddah tend to be theoretical that is "a united feeling between two individuals or more in a social class followed by affection and it lasts forever." 104

The Jews and Christians were depicted in the abovementioned verse as communities that greatly opposed to the prophet and his companions. The level of opposition was

${ }^{100}$ Ahmad Mukhtâr, Mu'jam al-Lughah al-'Arabiyyah al-Mu'âshirah, p. 1473.

${ }^{101}$ Reinhart Peter Andoze, Takmilah Ma'âjim al-Arabiah, Vol. VII (Baghdad: Wizârah al-Tsaqâfah wa al-I'lâm Jumhuriyah al-'Irâqiyah, 2000), p. 163.

${ }^{102}$ Mukhtâr, Mu'jam al-Lughah, p. 73.

${ }^{103}$ Nisywân al-Humairî, Syams al-'Ulûm wa Dawâk Kalâm al-'Araby min al-Kulûm, Vol. XI (Beirut: Dâr al-Fikri al-Mu'âshir, 1999), p. 7034.

${ }^{104}$ Mukhtâr, Mu'jam al-Lughah, p. 2417. 
maximum because it was already led to behavior and action. The history has recorded a series of hostile actions committed by the Jews in Medina toward the prophet after the peace treaty was made. They were harassing the Muslim community, committed rebellion, such as violating the contents of the peace treaty, and forming alliance with the musyrik people of Mecca in the Parit battle (khandaq). It is not less interesting to look back to the psychological war set by the musyrik people of Mecca through bullying and persecution, and even physical action towards the companions of the prophet. These actions were then flared up by a plan of executing Prophet Muhammad PBUH that was going to be done at night before hijrah as well as a series of open war in some battle fields.

The Christians are the third group mentioned in the previous verse, but the history record says that they had no hostility toward the prophet and his companions, unlike what the Jews and Musyrik group did. Although there was no name mentioned, the interpretation of the stated Christians refers to Najasyî (King of Habsyah) and the followers of 'Isa a.s. ${ }^{105}$ who met Islam and converted to it because they acknowledged the truth and felt small after knowing the truth. Al-Qissûn and al-ruhbân are the main subjects of the narration of this verse that depicted the Christian community. Al-Qissîsûn is plural, and the singular form is qisîs that means "the server of religion of Masehi/AD who also acts as the leader in every ritual practice." ${ }^{106}$ However, Râgib al-Ashfahânî assigns a meaning to qisîs as "a person who does dhikr (remembrance) frequently."107 Meanwhile, the word al-ruhbân is the plural form of al-râhib ${ }^{108}$ and the root word is rahaba tha means "hiding" or alienating oneself. Al-Azharî provided information about the habits of the Christian monks who alienated themselves in the monasteries. ${ }^{109}$ Ahmad Mukhtâr added some information about the characteristics of the Christian monks who complelety left the wordly pleasure, alienated themselves from the society, and perfomed ritual practices based on their belief and its procedures. ${ }^{110}$ Abu Hayyân al-Andalûsî provided an easier

${ }^{105}$ Ibn Katsîr said, as quoted by Sayyid Thanthâwî, that the group that claimed themselves as the Christians who follow Isya A.S was like Angela sect today. They had an emotional relationship with Islam and its followers, and it was only kept within their heart because they were the followers of Prophet 'Îsa a.s. Allah has explained this kind of Christian believers in surah al- $\underline{H}$ adîd/57: 27: "waja'alnâ fi qulûb al-ladzîna ittaba'ûhu ra'fatan wa rahmatan wa rahbâniyatan". Their holy book also says "To one who slaps your right cheek, give him your left cheek too." The crucial point in this sect shows that war is not a part of the principles of their religion. see: Muhammad Sayyid Thanthâwî, al-Tafsîr al-Washîth li al-Qurân al-Karîm, Vol. IV, p. 255.

${ }^{106}$ Ahmmad Mukhtâr, Mu'jam al-Lughah al-Arabiyyah al-Mu'âshirah, Vol. III, p. 1810.

${ }^{107}$ Abû al-Qâsim al-Husain, Tafsîr al-Râghib al-Ashfahânî, Vol. V (Thanthâ: Jâmi'ah Thanthâ, 1999), p. 419.

${ }^{108}$ Ibrâhîm al-Farâbî, Mu'jam Daiwân al-Adab, Vol. I (Kairo: Muassasah Dâr al-Sya'bî li alShahâfah wa al-Thibâ'ah wa al-Nasyri, 2003), p. 345.

${ }^{109}$ Muhammad al-Azharî, Tahdzîb al-Lughah, Vol. VI, p. 155.

${ }^{110}$ Ahmad Mukhtâr, Mu'jam al-Lughah al-Arabiyyah al-Mu'âshirah, Vol. II, p. 90. 
understanding for the words al-qissûn and al-ruhbân, which are translated into "the Christian scholars" and or "the Christian priests." 111

Taking a closer look, the etymological and terminological meanings of al-qissûn and al-ruhbân are different from the modern concept of the Christian priest although they still have the same spiritual position. The main differences include belief, spiritual activity, and action. Buhaira and Waraqah bin Naufal, for instance, believed in the prophecy of Muhammad PBUH and believed that he is the Messenger of Allah because the information is written in their holy book. Also, the monks who lived in Habsyah Kingdom after the era of Ja'far bin Abd Muthalib recited the verses of the Qur'an that were related to Prophet Isya A.S. In case of religious activities, al-qissûn and al-ruhbân indeed went for isolation in order to do worship and abandon the wordly pleasure. They implemented the teachings of Tawrat and Injil in their ritual practices so that they acknowledged the truth of the existence of prophet among the Arabic people.

The comparison of hostility level of the Jews and Christians communities will be more interesting if the verse above is observed and compared to the statement of Abû Hurairah, which stated that the prophet Muhammad PBUH said "mâ khalâ yahudiyâni bi muslimin illâ hammâ bi qatlih."112 It told about a condition in which two Jewish people who were hiding were killed, but on the other hand, the Christians, as a community and individual, did not go against the prophet and his companions as what al-qissûn and alruhbân ${ }^{113} \mathrm{did}$. Some of them were even crying when they listened to the recitation of the verses of the Quran. It was caused by many things, and it was mainly because of the Jews' arrogance while al-qissûn and al-ruhbân from the Christian community were known for having humility and modesty. ${ }^{114}$ Sirâjuddîn informed that "the Christians tended to have no feeling of jealousy toward other beliefs and did not hurt other human beings."115 As an addition to the characters and traits, religion was also believed as the other triggering factor of the hostility they committed. Al-Qâsimî affirmed that the Jews were obliged to spread hostility and terror to other people who have different religions using any ways. They did economic oppression and murder, but those things were forbidden for the Christians. ${ }^{116}$ This argumentation was asserted by al-Khathîb that the Christians did not consider the

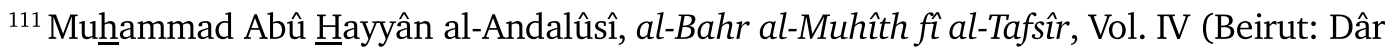
al-Fikrî, 1420), p. 344.

${ }^{112}$ Ibid., p. 344.

${ }^{113}$ Abû Ishâa Ahmad al-Tsa'labî, al-Kasyf wa al-Bayân 'an Tafsîr al-Qurân, Vol. IV (Beirut: Dâr Ihyâ al-Turâts al-'Arabî, 1418), p. 97.

${ }^{114}$ Al-Andalûsî, al-Bahr al-Muhîth fî al-Tafsîr, Vol. IV, p. 344.

${ }^{115}$ Sirâjuddîn 'Umar, Al-Lubâb fì 'Ulûm al-Kitâb, First edition, Vol. VII (Beirut: Dâr al-Kutub al-'Ilmiyah, 1998), p. 479.

${ }^{116}$ Muhammad Jamâluddîn al-Qâsimî, Mahâsin al-Ta'wîl, Vol. IV (Beirut: Dâr al-Kutub al-'Ilmiyah, 1418), p. 226. 
Abrahamic religions as their own. Meanwhile, the Jews thought that the Abrahamic religion was purely theirs, and other races were prohibited to embrace their religion or Islam. ${ }^{117}$

The comparison between the Jews' and Christians' level of attitude regarding "the softer relationship" is actually a reality in the real life, which was relevant in the era of prophet Muhammad PBUH, and it is way different if it is compared to the current era because every religion and belief has their own mission and vision. Moreover, the followers also have rivalry between a belief and another, but they also have the same forum to maintain peace and relationship. Sayyid Thanthâwî stated that "these praises were delivered only to solve crimes or other evil things. These were not the real praises because the words reflecting the hostility towards Islam and a little softer relationship or emotional relation are not justifying their $k u f r / d i s b e l i e f$ and their weakness. ${ }^{118}$

\section{In Search of a Balanced Social Communication}

The word ahl kitâb can be found many times in various verses in the Qur'an.The ahl kitâb mentioned here belong to the Jewish and Christian communities. Al-Thabarî explicates the meaning of ahl kitâb in this verse "the owner of two holy books" named Tawrat and Injil without taking a favor on one of the holy books' followers. ${ }^{119}$ These verses containing the word ahl-kitâb mostly tend to contain the teaching of tawheed, kufr, and their daily activities; moreover, those verses teach about negative behaviors, such as jealousy, grudge, arrogance, rebellion, and misleading. Allah the almighty, through the Qur'an, has shown His divine words towards Ahl Kitâb in facing the act of kufr and wrong ritual practices that were implemented in their daily life. In surah Ali-Imrân/3 verse 64, Allah declares: "qul yâ ahla al-kitâbi ta'âlau ilâ kalimah sawầ'in bainanâ wa bainakum allâ na'buda illa Allâha walâ nusyrika bihî syaiâ walâ yattakhidza ba'dunâ ba'dhan arbâban min dûni Allah fain tawallau faqûlû isyhadû biannâ muslimûn. (Say: O People of the Scripture. Come to an agreement) the agreement is: there is no god except Allah (between us and you: that we shall worship none but Allah) we shall declare Allah as the only One God, (and that we shall ascribe no partners unto Him) from among created beings, (and that none of us shall take others for lords beside Allah) that none of us shall obey another person in that which involves a transgression against Allah. (And if they turn away) and refuse to accept Allah's divine Oneness, (then say: Bear witness) know (that we are they who have surrendered (unto Him)) and acknowledge His Divine Oneness and worship Him.)

There are dissimilar opinions among the mufassir regarding the peculiarity of the revelation of this verse, whether it was sent down to the Jews from the Israel clan, or it

117 'Abd al-Karîm Yûnus al-Khathîb, al-Tafsîr al-Qur'ânî li al-Qurân, Vol. II, p. 561.

${ }^{118}$ Muhammad Sayyid Thanthâwî, al-Tafsîr al-Washîth li al-Qur'ân al-Karîm,Vol. IV, p. 255.

${ }^{119}$ Muhammad bin Jarîr al-Thabarî, Jâmi' al-Bayân fí Ta'wîl al-Qur'ân, Vol. VI, p. 485. 
was particularly sent down to the Christians, the people of Najran. ${ }^{120}$ Regardless the variation of opinions, al-Tsa'labi has elaborated the causes of the revelation of this verse that is the arrival of the Najran Christian community in Medina who also met the Jews community. This forum then triggered the debate about Prophet Ibrahim a.s. This debate then led them to ask Prophet Muhammad PBUH about a solution by saying "O Muhammad, we have different opinions concerning Ibrahim. The Christians assume that Ibrahim is Christian, and he is the most prominent human. The Jews also has the same claim. Prophet Muhammad PBUH then answers that none of these two communities are the followers of Ibrahim a.s., but he is a hanif (a person who maintained the pure monotheism of the patriarch Abraham) and I (Muhammad PBUH) have the same religion as his, and all of you should embrace his religion that is Islam." ${ }^{121}$

The word Sawâ written in the verse is interpreted as mustawiyah and is translated into "same." The sentence sawâ bainanâ wa bainakum is interpreted by al-Zumukhsyarî into mutatsâwiyah bainanâ wa bainakum that contains meaning "similar among us and you" and not differentiating the content of the Qur'an, Tawrat and Injil. ${ }^{122}$ Râghib alAshfahânî conveys that the word Sawâ is also interpreted as 'âdil ${ }^{123}$ which has the same meaning and use as an Indonesian word. The Indonesian words of "same" and "fair" are similar to one degree, one level, one position, in line, and contains no concept of belittling others. The word $a r b a \hat{b}$ is the plural form of $a l-r a b$ as what has been defined by Wahbah al-Zuhailî as ${ }^{124}$ "someone who takes a role as the respected person that protects, guards, obeys the commands and avoid the forbidden things. The most crucial element is having the right in tasyri (the establishment of Islamic law) regarding halal /lawful and haram/ prohibited." The phenomena of arbâb in the Ahl al-Kitâb community is explicated in more details by al-Thabarî who said "obey and follow the leaders who give orders to do sinful things and abandon everything forbidden by Allah the Almighty." 125 From those definitions, it can be concluded that the word arbâb refers to someone that is assumed to be a respected, influential, clever, and intelligent person who also possesses the authority to legalize and forbid things based on Islamic law.

${ }^{120}$ Najran is a small city in Hijaz at the famous Yemen, the place that was inhabited by two Hamdan tribes. The inhabitants are robbers or thieves, and they executed their actions in the borderline of Yemen. The Quran also wrote one verse that states ashhâb al-ukhdûd, which was assumed by an opinion that it was located in Najrân, and now Najrân is included as a part of Manthiqah 'Ashîr, Kingdom of Saudi Arabia. See: T. Pen, Hudûd al-Âlim min al-Masyriq ilâ al-Magrib, Vol. I (Kairo: al-Dâr al-tSaqâfah li al-Nasyr, 1423), p. 171. 'Âlî al-Harûwî, al-Isyârât ilâ Ma'rifah alZiyârât, Vol. I (Kairo: Maktabah al-Tsaqâfah al-Diniyah, 1423), p. 24.

${ }^{121}$ Abû Ishâq Ahmad al-Tsa'labî, al-Kasyf wa al-Bayân 'an Tafsîr al-Qur'ân, Vol. V (Beirut: Dâr Ihyâ al-Turâts al-'Arabî, 1418), p. 85.

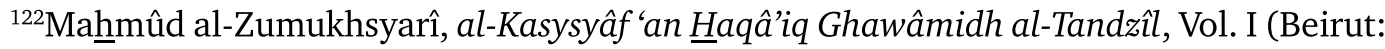
Dâr al-Kitâb al-'Arabî, 1422), p. 371.

${ }^{123}$ Abû al-Qâsim al-Husain, Tafsîr al-Râghib al-Ashfahânî, Vol. I, p. 330.

${ }^{124}$ Wahbah al-Zuhailî, al-Tafsîr al-Munîr fĩ al-'Aqîdah wa al-Syarî‘ah wa al-Manhaj, p. 251.

${ }^{125}$ Muhammad bin Jarîr al-Thabarî, Jâmi‘ al-Bayân fí Ta’wîl al-Qur'ân, Vol. VI, p. 488. 
Social communication is the command given to Prophet Muhammad PBUH, through the abovementioned verse, for doing Islamic preaching, conversing, and communicating with the Ahl al-Kitab community that consists of the Jews and Christians as the believers of Tawrat and Injil. The dialogue in a conversation should be arranged in kalimatin sawâ formula. ${ }^{126}$ This social communication is a form of their existence, but the principal materials encompass the acts of worshipping Allah the Almighty, refusing polytheism or animism, having no belief that one's intelligence is equal to Allah. This subject concerning communication is very vital because Ahl al-Kitâb, the Jews and Christians, made their loved ones as their God, namely 'Uzair and 'Isa a.s. and kept Allah the Almighty next to them.

\section{Conclusion}

Through the verses, the Qur'an has described the social communication that can be performed between Muslims to non-Muslims. The fiqh tafsîr analysis on those verses conclude the social communication form and format through dialogue, discussion, questionanswer session, as well as the social variable pointing out that all people are equally tall when standing and equally low when sitting without any assumption that the followers of other religions or beliefs are higher or lower. Knowing each other, acknowledging their existence by creating a peace treaty, forming a softer relationship with the followers of the Abrahamic religions, and conducting discussion based on equality with the Ahl alKitab community are the future social communications. Future research and studies on other verses of the Qur'an in order to elaborate the form and format of social communications that can be performed are essential to be conducted to be more specific and detailed references since this study is limited to global form and format only.

\section{References}

'Abbâs, Fadlu Hasan. al-Tafsîr wa al-Mufassirûn Asâsiyyâtuh wa Ittijâhâtuh wa Manâhijuh

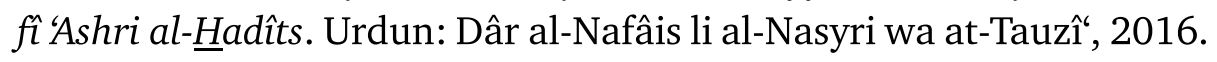

'Umar, Sirâjuddin. al-Lubâb fî 'Ulûm al-Kitâb. Beirut: Dâr al-Kutub al-'Ilmiyyah, 1998.

"The Definition of Social," in http://kbbi.web.id/sosial, August 29, 2016

Al-Anbarî, Muhammad. al-Zâhir fin Ma ânia al-Kalimât al-Nâs. Beirut: Mu'assasah al-Risâlah, 1992.

Al-Andalûsî, Ibn 'Athiyah 'Abd al-్aqqi. al-Muharrar al-Wajîz fî̀ Tafsîr al-Kitâb al-Azîz. Beirut: Dâr al-Kutub al-'Ilmiyyah, 1422.

Al-Andalûsî, Muhammad Abû Hayyân. al-Baḥr al-Muhîth fí al-Tafsîr. Beirut: Dâr al-Fikrî, 1420.

${ }^{126}$ Sayyid Quthub bin Ibrâhîm al-Syaribî, fi Zhilâl al-Qur'ân, Vol. I, p. 391. 
MIQOT Vol. 44 No. 2 July-December 2020

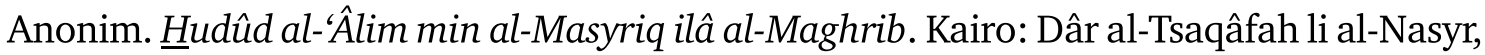
1423.

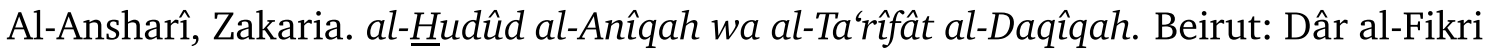
al-Mu'âshir, 1411.

Al-Azharî, Muhammad. Tahdzîb al-Lughah. Beirut: Dâr Ihyyâ' al-Turâts al-'Arabî, 2001.

Al-Ba'lî, Muhammad. al-Mathla' 'alâ Alfâzh al-Maqna'. n.p.: Maktabah al-Sawâdî, 2003.

Al-Baidhâwî, Nâshiruddîn. Anwâr al-Tanzîl wa Asrâr al-Ta'wîl. Beirut: Dâr Ihyâ al-Turâts al-Árabî, $1418 \mathrm{H}$.

Al-Bukhârî, Muhammad. al-Jâmi’ al-Musnad al-Shahîh $\underline{h}$. n.p.: Dâr Thûq an-Najât, 1422 H.

Al-Dzahabî, Muhammad ㅂusain. al-Tafsîr wa al-Mufassirûn. Kairo: Maktabah Wahbah, n.d.

Al-Farâbî, Ibrâhîm. Mu'jam Daiwân al-Adab. Kairo: Mu'assasah Dâr al-Sya'bî li al-Shahâfah wa al-Thibâ'ah wa al-Nasyri, 2003.

Al-Fayyûmî, Ahmad. al-Mishbâh al-Munîr fí Gharîb al-Syarh al-Kabîr. Beirut: al-Maktabah al-'Tlmiyyah, n.d.

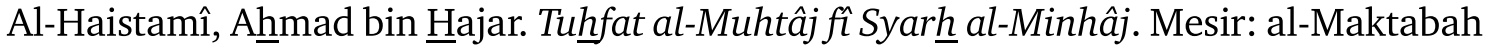
al-Tijariya al-Kubrâ, 1983.

Al-Haruwî, 'Âlî. al-Isyarât ilâ Ma'rifah al-Ziyârât. Kairo: Maktabah al-Tsaqâfah al-Diniyyah, $1423 \mathrm{H}$.

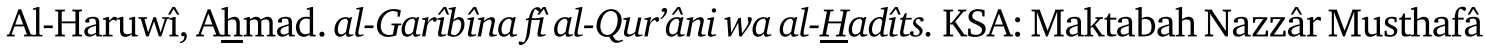
al-Bâz, 1999.

Al-Humairî, Nisywân. Syams al-'Ulûm wa Dawâk Kalâm al-'Araby min al-Kulûm. Beirut: Dâr al-Fikri al-Mu'âshir, 1999.

Al- Husain, Abû al-Qâsim. Tafsîr al-Râghib al-Ashfahânî. Thanthâ: Jâmi'ah Thanthâ, 1999.

Al- Husainî, Muhammad Murtadhâ. Tâj al-Arûsh min Jawâhir al-Qamûs. n.p.: Dâr alHidâyah, n.d.

Al-Jabbâr, M. 'Abd Saqâ. al-Tafsîr wa I'jâzz al-'Ilmi fî al-Qurân al-Karîm. Damaskus: Dâr Muhammad Amîn, 2010.

Al-Jashshâsh, Abû Bakar. Ahkâm al-Qur'ân. Beirut: Dâr al-Kutub al-'Ilmiyah, 1994.

Al-Jauharî, Ismấîl Hamda. al-Shahhâh Tâj al-Lughah wa Shahâh al-Arabiyah. Beirut: Dâr al-'Ilmi li al-Malâyîn, 1987.

Al-Jazâirî, Abu Bakr. Aysar al-Tafâsîr li Kalâmi al-'Aliyyi al-Kabîr. Madinah al-Munawarah: Maktabah al-'Ulûm wa al-ㅂukm, 2003.

Al-Khâlidî, Shalâh 'Abd al-Fattâh. al-Tafsîr wa al-Ta'wîl fí al-Qur'ân. Yordania: Dâr al-Nafầis, 1996.

Al-Khathîb, Abd Karîm Yûnus. al-Tafsîr al-Qur'ânî li al-Qurân. Kairo: Dâr al-Fikri al-Árabî, n.d. Al-Khathîb, Muhammad, Taisîr al-Bayân li Ahkkâm al-Qurân. Syiria: Dâr al-Nawâdir, 2012. 
Al-Marâghî, Ahmad. Tafsîr al-Marâghî. Mesir: Musthafâ al-Bâb al-Hâlabî, 1942.

Al-Mubarrad, Jamaluddîn. al-Dur al-Naqîfí Syarh Alfâzh al-Khurqî. Jeddah: Dâr al-Mujtama' li al-Nasyri wa al-Tauzî̀, 1991.

Al-Mujaddî, Muhammad 'Amîm al-Ihnsân. al-Ta'rifât al-Fiqihiyah. Beirut: Dâr al-Kutub al'Ilmiyyah, 2003.

Al-Na'îm, 'Abîr bin 'Abdillâh. Qawâ'id al-Tarjîh al-Muta'alliqah bi al-Nashshi 'inda Ibn 'Ashûr fi Tafsîri al-Tahrîr wa al-Tanwîr-Dirâsat Ta'shiliyah Tathbiqiyah. Riyadh (KSA): Dâr al-Tadmiriyyah, 2015.

Al-Nirbânî, 'Abd al-Badi'. al-Jawânib al-Shautiyah fỉ Kutub al-Ihtijâj li al-Qirâ'ât. Damaskus: Dâr al-Ghautsânî, 2006.

Al-Qâsimî, Muhammad Jamaluddîn. Mahâsin al-Ta'wîl. Beirut: Dâr al-Kutub al-'Ilmiyah, 1418.

Al-Qaththân, Mannâ' Khalîl. Mabâhits fĩ 'Ulûm al-Qur'ân. Riyadh: Maktabah al-Ma'ârif li al-Nasyri wa al-Tauzî‘, 2000.

Al-Râzî, Fakruddîn. Mafâtîh al-Ghaib. Beirut: Dâr Ihyâ al-Turâts al-'Arabî, 1420.

Al-Râzî, Zainuddîn. Mukhtâr al-Shahâh. Beirut: al-Maktabah al-'Ashriyah, 1999.

Al-Rûmî, Fahd. Dirasât fí 'Ulum al-Qurân al-Karîm. n.p.: n.p., 2003.

Al-Rûmî, Fahd. Ittijâhât al-Tafsîr fi al-Qarn al-Râbi’ 'Asyara. KSA: n.p., 1986.

Al-Sa'dî, 'Abdurrahmân, Taisîr Karîm al-Rahmân fí Tafsîr Kalâm al-Manân. n.p.: Mu'assasah al-Risâlah, 2000.

Al-Syinqithî, Muhammad al-Amîn al-Mukhtâr. Adhwâ al-Bayân fî Î Ihâh al-Qurân bi alQurân. Beirut: Dâr-al-Fikri, 1995.

Al-Thabarî, Muhammad bin Jarîr. Jâmi' al-Bayân fî Ta'wîl al-Qurân. n.p.: Mu'assasah alRisâlah, 2000.

Al-Thayyâr, Musâ'id. Fushûl fỉ Ushûl al-Tafsîr. n.p.: Dâr Ibn al-Jauzî, 1423.

Al-Tsa'âlibî, 'Abd Rahmân. al-Jawâhir al-Hisân fî Tafsîr al-Qurân. Beirut: Dâr Ihyâ alTurâts al-'Arabî, 1418.

Al-Tsa'labî, Abû Ishhâq Ahmad. al-Kasyf wa al-Bayân 'an Tafsîr al-Qurân. Beirut: Dâr Ihyâ al-Turâts al-'Arabî, 1418.

Al-Zuhailî, Wahbah. al-Tafsîr al-Munîr fí al-Aqîdah wa al-Syarî'ah wa al-Manhaj. Damaskus: Dâr al-Fikri al-Mu'âshir, 1418.

Al-Zumukhsyarî, Mahnû̂d. al-Kasysyâf'an ㅁaqâiiq Ghawâmidh al-Tandzîl. Beirut: Dâr alKitâb al-'Arabî, 1407.

Amir, M. Etika Komunikasi Massa Dalam Pandangan Islam. Jakarta: Logos Wacana Ilmu, 1999.

Andoze, Reinhart Peter. Takmilah Ma'âjim al-Áabiah. Baghdad: Wizârah al-Tsaqâfah wa al-I'lâm Jumhuriyah al-'Irâqiyah, 2000. 
MIQOT Vol. 44 No. 2 July-December 2020

Baidan, Nashruddin. Wawasan Baru Ilmu Tafsir. Yogyakarta: Pustaka Pelajar, 2005.

Effendy, Onong Uchjana. Ilmu Komunikasi: Teori dan Praktek. Bandung: Remaja Rosdakarya, 1999.

Golouse, Ahmad. al-Sîrah al-Nabawiyyah wa al-Da'wah fí 'Ahd al-Madnî. n.p.: Mu'assasah al-Risâlah li al-Tibâ‘ah wa an-Nasyri wa al-Tauzî‘, 2004.

Ibn 'Ashûr, Muhammad al-Thâhir. al-Tahrîr wa al-Tanwîr: Tahrîr al-Ma'na al-Sadîd wa Tanwîr al-Ma'na al-Jadîd min Tafsîr al-Kitâb al-Majîd. Tunisia: Dâr al-Tunisiyah li al-Nasyri, 1984.

Ibn al-Jauzî, 'Abd Rahmân. Zâd al-Masîr fị 'Tlm al-Tafsîr. Beirut: Dâr al-Kitâb al-Aarabî, 1422.

Ibn Hisyâm, 'Abd al-Mâlik. al-Sîrah al-Nabawiyah. Mesir: Syirkah Maktabah wa Mathba'ah Musthafâ al-Bâbî al-Halâbî wa Aulâdih, 1955.

Ibn Manzhûr, Muhammad. Lisân al-Aarab. Beirut: Dâr al-Shâdir, 1414.

Ibn Qutaibah, 'Abdullâh. Ta'wîl Musykil al-Qurân. Beirut: Dâr al-Kutub al-'Ilmiyah, n.d.

Ibrâhîm Musthafâ, et al. al-Mu'jam al-Wasîth. n.p.: Dâr al-Da'wah, n.p.

Imron, Ali. "Interaksi Sosial Muslim dan Non-Muslim Perspektif Maqâshid al-Syarîah," in http://repositori.uin-alauddin.ac.id/2216/, October 24, 2019

James G. Robbins dan Barbara S. Jones. Komunikasi Yang Efektif, tr. Turman Sirait. Jakarta: CV Pedoman Ilmu Jaya, 1986.

Makkî, Muhammad. al-Hidâyah ilâ Bulûg al-Nihâyah fin 'Ilm Ma'ânia al-Qurân wa Tafsîrih wa Ahkâmih wa Jumal min Funûni 'Ulûmih. Syarjah: Jâmi'ah al-Syâriqah, 2008.

Mukhtâr, Ahmad. Mu'jam al-Lughah al-Arabiyah al-Mu'âshirah. n.p.: 'Âlam al-Kutub, 2008.

Muslim, Musthafâ. Mabâhîtts fî al-Tafsîr al-Maudhû̂î, n.p.: Dâr al-Qalâm, 2005.

Nurdin, Ali. "Akar Komunikasi Dalam Al-Qurân," in Jurnal Kajian Komunikasi, Vol. 2, No.1, 2014, p. 12-26.

Qal'âjî, Muhammad Ruwâs dan Qanbî, Hâmid Shâdiq. Mu'jam Lughah al-Fuqahâ. n.p.: Dâr al-Nafâisy li al-Thibâ'ah wa al-Nasyr, 1988.

Quthb, Sayyid. Fî Zhilâl al-Qur'ân. Beirut: Dâr al-Syurûq: 1412 H.

Rahman, Andi. "Relasi Muslim dan Non-Muslim," in http://journal.uinjkt.ac.id/ index. php/kordinat/article/view/6331, October 15, 2019.

Rakhmad, Jalaluddin. Psikologi Komunikasi. Bandung: Remaja Rosdakarya, 1996.

Samsu. "Interaksi Sosial Muslim kepada Nonmuslim," in Jurnal Al-Munzir, Vol. 8. No. 2, 2015, p. 247-258.

Shâlih, Subhi. Mabâhitits fỉ 'Ulûm al-Qurân. n.p.: Dâr al-'Ilmi li al-Malâyîn, 2000.

Shofa, 'Abd Mu'id Aris. "Memaknai Kembali Multikulturalisme Indonesia Dalam Bingkai Pancasila," in Jurnal Pancasila dan Kewarganegaraan, Vol. 1, No. 1, 2016.

Sikumbang, Ahmad Tamrin. "Teori Komunikasi: Pendekatan, Kerangka Analisis dan Perspektif," 
in Analytica Islamica, Vol. 2, No. 1, 2017.

Sumarjo. "Ilmu Komunikasi Dalam Al-Qurân," in Jurnal Inovasi, Vol. 8, No 1, 2011.

Suryadilaga, M. Alfatih. Metodologi Ilmu Tafsir. Yogyakarta: Teras, 2010.

Syahnan, Mhd. "Al-Tabari's and al-Tabarsi's Interpretation of Qur'an 2:106: An Analysis of Their Approach to Tafsir," in The Dynamics of Islamic Civilization. Yogyakarta: Titian Ilahi Press: 1998.

Syahnan, Mhd. "Islam as a System: A Critical Analysis of Sayyid Quthb's Principle Thought," in Analytica Islamica, Vol. 4, No. 1, 2002.

Syahnan, Mhd. "Modern Qur'anic Exegesis and Commercial Contracts: A Comparative Study of Rashid Ridha's and Sayyid Qutb's Interpretation of Some Riba Verses," in Jurnal Miqot, 1997.

Syahnan, Mhd. "Modern Qur'anic Exegesis and Commercial Contracts: A Comparative Study of Rashid Ridha's and Sayyid Qutb's Interpretation of Some Riba Verses," in Jurnal Miqot, 1997.

Syahnan, Mhd. "Notes on the Origin and Methods of the Fi Zilal al-Qur'an of Sayyid Qutb," in Dinamika Ilmu, Vol. 2, No. 3, 2001.

Syahnan, Mhd. "The Image of the Prophet and the Systematization of Ushul al-Fiqh: A Study of al-Shafi'i's Risâlah", in Jurnal Miqot, No. 103, 1998.

Syukur, Abdul. "Mengenal Corak Tafsir al-Qurân," in Jurnal al-Furqania, Vol. 01, No. 01, 2015.

Thanthâwî, Muhammad Sayyid, al-Tafsîr al-Washîth li al-Qurân al-Karîm. Kairo: Dâr alNahdhah Misir li al-Thibâ'ah wa al-Nasyri wa al-Tauzî’, 1998.

Widagdo, Haidi Hajar. "Interaksi Sosial Muslim dengan Non-Muslim Perspektif Hadis". Thesis Universitas Islam Negeri Sunan Kalijaga, Yogyakarta, 2011. 